\title{
The Islamic Injunction on Hijab: \\ The Practice and The Dynamics of The Agitation \\ For The Adoption of The Use of Hijab in Ekiti State
}

\author{
Mufutau Olusola Bello \\ Ekiti State University, Ado-Ekiti, Nigeria \\ abumahfouzekiti@yahoo.com
}

\begin{abstract}
Ekiti State is one of the States in South Western part of Nigeria.. The major challenge facing the Muslims in this state is the Islamophobic tendencies of Christian dominated government on the usage of hijab by the female Muslims. The work investigates the challenges faced by the female Muslims as a result of their usage of Hijab and the response by the state government to various agitations by the Muslims on the subject matter. It made use of both primary sources such as relevant Islamic literatures on the subject of hijab, archival materials such as correspondences and pamphlets on the struggles for the usage of hijab in the state. These materials were domiciled in the state secretariats of the Supreme Council for Islamic Affairs and the League of Imams and Alfas. Also interviews were made with some Muslim stakeholders such as the executive members of the Supreme Council for Islamic Affairs, League of Imams and Alfas, and the Muslim Students' Society of Nigeria, while few Muslim principals of secondary schools in the State and some other few Muslim personalities in the state were also interviewed. The result revealed a good approach adopted by the government of Ekiti State in taking care of the agitations of the Muslims on the use of hijab in government official places of work and students in formal public schools. The Ekiti model is therefore suggested to be adapted and adopted by other states in Nigeria where the problem of hijab have snowballed into crises.
\end{abstract}

Keywords: Hijab, Ekiti State, Islamic Injuction

\section{Introduction}

Ekiti State was created out of Ondo State on $1^{\text {st }}$ of October, 1996.other states that were created alongside with Ekiti are Bayelsa, Ebonyi, Nasarawa, Gombe and Zamfara. ${ }^{1}$ Ekiti, meaning "hilly country side" is bounded by Osun

1 Ekiti State Government, Ekiti State Annual and Who's Who (Lagos: Medujet Publications, 1999), 13.

AJIS : Academic Journal of Islamic Studies, vol. 5, no. 2, 2020

IAIN Curup - Indonesia | ISSN 2580-3174, (p); 2580-3190 (e)

DOI: $10.29240 /$ ajis.v5i2.1836 | page: $197-208$ 
State in the West, Kwara State in the North, Kogi State in the North East and Ondo State in the South East. ${ }^{2}$ The state is unique with its landscape which consists of ancient plains broken by steep-sided ridges and notable rocks such as the ones found in Efon Alaaye-Ekiti, Ikere-Ekiti and Okemesi-Ekiti. ${ }^{3}$ It is the only State with warm and cold springs flowing side by side in Nigeria (Ikogosi Springs which is serving as a tourist center, source of drinkable water, fishing and agriculture. ${ }^{4}$

Linguistically, Islam means peace but technically, it is the name of the religion practiced by the Muslims. The adherent of the religion is about 1.8 billion across the globe. ${ }^{5}$ In Nigeria the population of those practicing the religion is about 90 million making it the largest Muslim population in subSaharan Africa. ${ }^{6}$ There are universal norms and practices adopted by whoever claims to accept the religion. One of such is the use of hijāb by the female adherents. Literally, hijāb refers to whatever that can shield something from being seeing. The term often refers to a Muslim women dress while a woman who adopts this wear is known as Mājubah. ${ }^{7}$

Adorning hijāb by the Muslims in South western Nigeria came with challenges in some states within the geo-political zone. For instance, it led to litigations in Osun, Oyo, and Lagos States. While the Muslim women regards wearing hijāb as part of their fundamental human right, the government in these States claimed that Nigeria is a secular state where one religion should not dominate other. In the mist of all this crises, Ekiti State with the least Muslim population ratio in the geo-political zone came out with a model that permit the Muslims to put on hijāb in government public schools and work places. It is on record that the issue of hijab has caused more rancor in the public sphere in south western Nigeria in the last two decades either involving government or government officials and the Muslims or adherents of other religions and

\footnotetext{
${ }^{2}$ Ekiti State Government, Ekiti State City Guide (Ado-Ekiti: Kunbi Publishers, 2004), 1.

${ }^{3}$ Ekiti State Government, Ekiti Yellow Pages (Ado-Ekiti: Kalda Investment Ltd., 2005), 12.

${ }^{4}$ Ekiti State Government, Ekiti State Annual and Who's Who, 12.

5 Islam By Country, "World Muslim Population By Percentage 2014 Estimate," Wikipedia, n.d., https://en.m.wikipedia.org/wiki/Islam_by_country.

6 "Religion in Nigeria," Wikipedia, n.d., https://en.m.wikipedia.org/wiki/Religion_in_Nigeria.

7 Mufutau Olusola Bello, "Dress Code in Tertiary Institution in Ekiti State: An Islamic Perspective" (M.A. Thesis, Department of Religious Studies, Ekiti State University, 2011), 21.
} 
Muslims. This paper does intent to find a lasting solution to the age long crises associated with the usage of hijab using Ekiti State model

\section{Literature Review}

Literatures on this subject matter would be reviewed thematically. Two key words are germane in this discussion, they are culture and hijäb. Hence, the work will review materials on culture in relation to dressing and in particular to Yoruba culture of the southwestern Nigeria. It will also review material on positions of Islam on the usage of hijāb in Islam.

A.B. Mamman viewed culture in a broad term that encompasses dressing. He claims it has assumed different definitions for decades. The crisis of too many definitions for culture propels Reger Keesing to say that the challenge facing culture now is how to narrow its concept so that it includes less and reveals more. ${ }^{8}$ In his part, Philip T. Ahire made reference to some orthodox scholars' attempts at defining culture. He quoted Malinowski who defines culture as that complex whole which includes knowledge, belief, art, law, moral, custom and all other capabilities and habits acquired by man as a member of the society. ${ }^{9}$ In the pre-colonial times, Ahire claimed each of the numerous ethnic groups in Nigeria had a distinct and cohesive culture. He said it was easier to recognize people, through their actions and appearances, as belonging to Yoruba, Hausa, Ibo, Tiv, Efik or Nupe culture. ${ }^{10}$

Ayanniyi B. Alhasan, in his own submission, concludes that African culture has been affected by factors such as Arab imperialism, the slave trade, Muslim Proselytization, the human export (European slave trade) western colonization, imperialism and accompanying Christian missionary influences. ${ }^{11}$ The New Encyclopedia Britannica sees dress as covering or clothing and accessories for the human body. It believes that the term "dress" encompasses not only such familiar garments as skirts, trousers, jackets and coats but also foot wears, caps, hats, sleep wears, sport clothes, corsets and gloves. ${ }^{12}$

C.L. Adeoye, wrote that the Yorubas adorn themselves with a unique dress. The men according to him wear buba (blouse or shirt) and sokoto (trousers) with

8 Igoli Nasidi, Culture and Democracy (Zaria: Ahmadu Bello University Press Limited, 2002), 289.

9 Ibid., 95.

10 Ibid., 289.

11 Ibid., 275.

12 Encyclopedia Britannica, Inc, “The New Encyclopedia Britannica" (Encyclopedia Britannica, Inc, 2007), 222. 
many variants like Latan or Abidan, Soro, Atu, Kamu, Abantara and Mangudu. Apart from Kembe that is slightly baggy to allow for breathing. On top of buba and sokoto is agbada, (the flowing robe with wide sleeves). The more important the event, the more decorative the embroidery becomes. Agbada is generally reserved for special occasions. ${ }^{13}$ Adeoye stressed further that the women also adorn themselves with buba and Iro. Buba is the blouse, which may have embroidery or not and this largely depends upon the purpose in which the outfit is been worn while iro is the wrapper, it is a large piece of square cloth that may or may not be the same colour. Gele is the head scarf or gear. ${ }^{14}$

The term 'awrah refers to the part of the body that are necessary to cover for both men and women in Islam. Jamal A. Badawi maintained that the part of men that must be covered is from the navel to the kneel ${ }^{15}$ while that of women according to some scholars is the entire body. Though he believed that majority of scholars however agree that the face and the hands may be left uncovered. ${ }^{16}$ Muhammad Nasir-Albāni permit the exposure of the face and feet ${ }^{17}$ while AlBahla is of the view that these areas should be covered. ${ }^{18}$

\section{Result of findings}

The agitation for the use of hijāb could be traced to Awo Community Comprehensive High School, Awo-Ekiti in 2011, when the daughter of the Imam of the town was forcefully asked to remove his hijāb by a teacher in the school. The intervention of the Imam led to a misunderstanding between him and the school management. The uncompromised Muslim Students took the advantage to express their displeasure for not allowing the use of hijāb in the school. This eventually led to a riot and the school was closed down for a week.

On 29th October, 2013, the Nigeria Supreme Council for Islamic Affairs, Ekiti State Chapter wrote the Executive Governor of the State, in a letter titled "Cases of Recurring Persecution and Threat to Life and Career Based on the Usage of Hijāb: Urgent Appeal from Ekiti Muslim Community". The letter

${ }^{13}$ C.L. Adeoye, Asaatilse Yoruba (London: University Press Limited, 1980), 21617.

14 "Fashion in Nigeria," Wikipedia, n.d., https://en.wikipedia.org/wiki/Fashion_in_Nigeria.

15 Jamal A. Badawi, Woman under the Shade of Islam (Riyadh: Organization of Islamic Conference, 1998), 55.

16 Ibid., 50.

17 Muhammad Nasir al-Din Albani, Hijab al-mar'ah al-Muslimah fi al-Kitab waal-Sunnah (Beirut: al-Maktab al-Islami, 1997), 26.

18 Farihu Ibn Salih Al Bahla, Al-Istihabbu Fi Mã Qila Fi'l Hijāb (Beirut: Dar al Kutub, 1426), 3. 
recalled how Mr. Lawal, a principal of Saliu Adeoti Memorial Comprehensive High School, Otun-Ekiti and Aladejobi Abdul Azeez also a principal at Ikosu Comprehensive High School Moba Local Government were persecuted by the Christian Principals, the Area Education Officers and the Permanent Secretary, Ministry of Education and Technology in the State. ${ }^{19} \mathrm{Mr}$. Lawal had after a persistent request and consultations allowed the Muslim females students in his school to wear hijāb. Pastor Adetola, a member of the School Based Management Board, was said not to be favorably disposed to its usage.

When the Muslims were battling to bring all those that harass the duo of Mr. Lawal and Mr. Aladejobi to justice, a letter emanating from Ministry of Education, Science and Technology, Ekiti State on the $21^{\text {st }}$ of November, 2013 banned the usage of hijāb in any of the public schools in the State.20 The implication of this is that the Muslim faith based schools and few community schools where hijāb is been used would be stopped.

In a swift reaction to the letter from the Ministry of Education, Science and Technology, the Supreme Council for Islamic Affairs, Ekiti State and the Muslim Students' Society of Nigeria, Ekiti State wrote differently to the Governor expressing their fair on the faith of the Muslims in the State on the prevention of their female's pupils/students from wearing hijäb. The National Council of Muslim Youth Organization of Nigeria, Ekiti State equally wrote a letter to the Permanent Secretary, Ministry of Education, Science and Technology, Ekiti State to express their displeasure on the letter banning the use of hijāb in all public schools in the State. ${ }^{21}$

The State government in his reaction to all cries and the hues of the Muslims through writings, public sermons and representations to the government released a letter dated $12^{\text {th }}$ December, 2013 that allowed the use of hijāb in public schools. The circular letter among others state that:

1. the mode of dressing in any faith based school may reflect the religion inclination of that school;

19 The Nigeria Supreme Council for Islamic Affairs, Ekiti State Council Ref No: EK/SCIA/05/2013 dated 29th October, 2013

${ }^{20}$ Circular letter from the Ministry of Education Science and Technology, Ekiti State of Nigeria Ref No: EK/ED/SCHLS/SEC/1506/82 dated 21st November, 2013

21 The Nigeria Supreme Council for Islamic Affairs, Ekiti State Council letter was titled "Re Cases of Recurring Persecution and Threat to Life and Career Based on the Usage of Hijab: Appeal from Ekiti Muslim Community dated 2nd December 2013, while the National Council of Muslim Youth Organizations of Nigeria, Ekiti State Chapter was titled "Re-Issue of Hijab in Ekiti State Schools" dated 2nd December, 2013 
2. in other public and community schools, desired student Muslim faithful could dress in acceptable hijāb.22

This step taken by the state government has lain to rest the agitation for the use of hijāb in the State. However, the clause that limit the use of hijāb to Muslim faith based schools and the community schools is still been debated by the concern Muslims in Nigeria. The National Amir of the Muslim Students' Society of Nigeria has in different fora condemned the limitation.

The persecution of the Muslims is not limited to students. Adesola Muniat Adenike recalled how she was persecutions by the ministry officials of Ekiti State government in 2004 when she was looking for job. According to her, the persecution was based on the usage of hijāb. She said she was advised on many occasions to put off the hijāb so that she could be employed. ${ }^{23}$ In 2011, two female Muslims were deprived of promotion interview. It was when the cases degenerated and protest was made to the government that a circular letter was issued to douse the tension and allowed female Muslims in public service to dress modestly in accordance with the dictate of their religion. ${ }^{24}$

\section{Discussion}

The Muslim women dress code is called Jilbāb (literally meaning a screen, barrier, cover or veil, etc) while the apparel that they use in covering themselves up is referred to as hijab The regulation concerning Islamic dresses for both men and women are evident in the Qur'ān 24: 30-31 as follows.

Say to the believing men that they should lower their gaze and guard their modesty; that will make for greater purity for them: And God is well acquainted withal that they do. And say to the believing women that they should lower their gaze and guard their modesty; that they should not display their beauty and ornaments except what (must ordinarily) appear thereof; that they should draw their veils over their bosoms and not display their beauty except to their husbands, their fathers, their sons, their husbands' sons, their brothers or their brothers' sons, or their sisters' sons, or their women, or the slaves whom their right hands possess, or male servants free of physical needs, or small children who have no sense of the shame of sex; and that they should not strike their feet in order to draw attention to their hidden ornaments...

${ }^{22}$ Circular letter from Office of Ekiti State Government, Ref. No. EK/SSG/01/375 dated 12 th December, 2013

${ }^{23}$ Interview with Adesola Muinat Adenike. A teacher with the Teaching Service Commission, Ekiti State on 1st of October, 2011

${ }^{24}$ Circular letter from Office of Ekiti State Government, Ref. No. EK/SSG/01 dated 3rd June, 2011 
From these verses, eight conditions that the dressing of Muslim women must satisfy were itemized.

1. The Jilbāb must not be an adornment in itself

2. The Jilbāb (a big and a flowing garment) must be worn by women in addition to the Khimar (head-scarves) when going out.

3. It must be thick and not transparent,

4. It must not be a tight-fitting dress,

5. There must not be scent on the cloth, (especially when wearing it outside the home).

6. The dress must not resemble that of men.

7. It must not resemble that of non-Muslims.

8. The dress must not be worn for show. 25

From the verses, it is also said that the requirements for female dress are four. The first is the extent of covering. This must cover the whole body except the areas specifically exempted by the Qur'ān. Such areas are the face and the hands. The second requirement is that, the dress must be loose enough so as not to reveal the shape of a woman's body. And the third is that the dress should be thick enough so as not to show the colour of the skin it covers or the shape of the body which it is supposed to hide. While the last requirement is the overall appearance; that is, the dress should not be such that would unnecessarily attract men's attention. ${ }^{26}$

Also, the additional requirements for female dress are that their applications may vary with time and location. These are:

1. the dress should not be similar to what is known as a male costume.

2. it should not be similar to what is known as the costume of unbelievers.

3. it should not be a dress of fame, pride and vanity. 27

The requirements of the Muslim women's dress apply as well to the Muslim men dress, according to Badawi, except for the differences in the 'awrah for both of them. The 'awrah for women is their whole body according to some

25 Badawi, Woman under the Shade of Islam, 48-53.

${ }^{26}$ Al Bahla, Al-Istihabbu Fi Mã Qila Fi'l Hijāb, 3.

27 Albani, Hijab al-mar'ah al-Muslimah fi al-Kitab wa-al-Sunnah, 26. 
scholars ${ }^{28}$ while some scholars exempt their faces and hands. ${ }^{29}$ For the men, their 'awrah is defined as the area between the navel and the knees. ${ }^{30}$

From the foregoing, it could be concluded that, the Hadith had presented the two sides of the issue, which one is the best remains a matter of opinion. However, there is no such dispute over what constitutes a woman's 'awrah that must be covered, except her hands and face as said by Allah in the Qur'ān 33:59 "O Prophet! Tell thy wives and your daughters, and the believing women, that they should cast their outer garments over their persons (when abroad): That is most convenient, (as such) and not molested...."

Scholars differ on where to cover when outside their homes. For instance some concludes that a woman is allowed to uncover her face and hands ${ }^{31}$ while others hold tenaciously to the belief that the face veil is compulsory for Muslim women ${ }^{32}$. In his own part it is also opined that the ruling of the face-veil is applicable only to the wives of the Prophet. ${ }^{33}$

Essentially, the manner of dressing is important in Islam. In fact, members of the opposite sexes are forbidden to appear in similar dresses.

It was narrated by Ibn 'Abbas that the Prophet (SAW) cursed effeminate men, those men who are in the similitude of women and those women who assume the manners of men and he said, "send them out of your houses". The Prophet (SAW) sent out such and such man and 'Umar sent out such and such women. ${ }^{34}$

The basic truth is that anything, be it a name, a dress or food, etc., that does not violate the provisions of Qur'ān and the Sunnah may be called Islamic. In the same vein, any dress style that meets the Islamic requirements is acceptable. A new Muslim does not have to adopt a foreign style of dress, but may find a way to adapt his or her customary dress in any way that pleases him

\footnotetext{
28 Badawi, Woman under the Shade of Islam, 48-53.

${ }^{29}$ As-Sayyid Sabiq, Fiqh Us-Sunnah (USA: American Trust Publications, 1991), 111.

30 Ibid.

${ }^{31}$ Albani, Hijab al-mar'ah al-Muslimah fi al-Kitab wa-al-Sunnah, 26.

32 Muhammad Muhsin Khan, Sahih Al-Bukhāri Arabic-English (Riyadh: Darussalam, 1994), 949.

33 Train the Trainers Course (TTC) Beginners Module 101, Mina: IET)

${ }^{34}$ Circular letter from Office of Ekiti State Government, Ref. No. EK/SSG/01 dated 3rd June, 2011
} 
or her and covers his or her body in conformity with the Islamic standard of modesty. ${ }^{35}$

Consciously or unconsciously, many female Muslims are using hijab in Ekiti State. The usage is more by the female youths than the aged ones. Out of about one hundred and sixteen public secondary schools in the State, only six were faith based Muslim schools. Muslim Students in these schools have been using hijäb for more than a decade while few other community schools also have hijāb as part of their dressing by the Muslim students. ${ }^{36}$

It has been observed that the denial of hijā $b$ to Muslims is a clear violation of the fundamental human rights of Muslims. ${ }^{37}$ The constitution of the Federal Republic of Nigeria, 1999 provides as a fundamental human right, the right of every person to freedom to manifest ones religion in practice and observance. 38 The Constitution also provides safeguards against discrimination on ground of religion. ${ }^{39}$ Both sections are part of the fundamental rights provisions of the constitution which constitutes the bill of rights, embodied in the constitution. It has also been noted that the use of hijāb is practically a matter of freedom of choice of a Muslim woman as a matter of freedom of religious expressions. ${ }^{40}$ The freedom of worship and observance of one's religion either in public or private alone or in the community with others is a fundamental right which forms part of the core of international human rights standard. ${ }^{41}$

\section{Conclusion}

Dressing in Ekiti State generally is not different from those of other Yorubas. The different types of clothes worn by the males are buba and sokoto while the females mostly wear buba and iro with gele. These types of wears by the Yorubas have not in any way been seen as infringements on the Islamic mode

35 Interview with Shaikh Ahmad Yusuf, a teacher with the Teaching Service Commission, Ekiti State on the 3rd of November 2013

${ }^{36}$ Interview with Abdusalam Ayoola Agbaje, the Chief Imam of Awo-Ekiti on the 3rd of November, 2013

37 Nimatallah Modupe Abduraheem, “The Hijāb, Barristers' Dress Code and Religious Freedom in the Legal Profession in Nigeria," 2014, www.unilorin.edu.ng.

38 "Constitution of Nigeria," accessed January 10, 2021, http://www.concourt.am/armenian/legal_resources/world_constitutions/constit/nig eria/nigeri-e.htm.

${ }^{39}$ Ibid., sec. 42 (1).

${ }^{40}$ Abduraheem, "The Hijāb, Barristers' Dress Code and Religious Freedom in the Legal Profession in Nigeria," 12.

41 "Universal Declaration of Human Rights," October 6, 2015, https://www.un.org/en/universal-declaration-human-rights/. 
of dressing. For instance, some requirements of the Islamic female dresses are that, the dresses must not be tight fitting and should not resemble that of men. They must not be worn for show, pride and vanity while the males are required to cover the front and back of their private parts.

It is pertinent to note that Whenever Islam reaches any environment, its culture will only moderate the people's ways of life and culture that is alien to the Islamic culture that it brought and at the same time imbibing those that are in tandem with it. This is what actually played out in Ekiti State. The presence of Muslims in the state has influenced the dressing pattern of the people of the state. A Muslim woman would always put on a loose cloth round her neck up to her bosom whenever she is going out of the house. By and large, this was adopted by almost every woman in the community. The gele, worn by the Yoruba women show that they neither uncover their heads nor expose their bosoms when outside their homes. The Muslim men's dressing has not departed so much from the traditional way of dressing of the Ekitis. They continue to appear with no clear distinction from other non-Muslims in the state. The exception to this is only during the time of their festival and the Jumu'at days when many of them put on Arabian wears.

The gele worn by the Yoruba women shows that they neither uncover their heads nor expose their bosoms when outside their homes as Allah commands the believing Muslim women too to cast their outer garments over their persons when outside their homes. It was revealed in this paper that, an average Yoruba woman do not go out of her house without putting on gele. The paper also revealed that the use of hijäb is compulsory in Islam by the female Muslim as stipulated by Allah and His Prophet. It equally observed that the Muslim way of dressing is in-tandem to the dressing in Yoruba land and Ekiti State inclusive.

It is noteworthy to say that the intervention of Ekiti State government to come out with an agreed dress code for Muslim students in public schools is novel in the south western part of Nigeria. Also documented letter to all government agencies allowing the Muslim female workers the use of hijab in their various offices should be commended. I wish to recommend that other states in the geo-political zone of the country where the use of hijab is still causing one problem or the other should borrow a leave from Ekiti State government. It should also be noted that various individuals who take laws into their own hands by unnecessary discrimination of the hijab usage should desist for the peaceful co-existence of the citizenry. 
The State Government has seen to have viewed the agitations by the Muslims to wear hijāb as a means to make them modest and practice their religion as dictated by Allah as well as fulfillment of their fundamental human right. This has led to the government modest means of solving the problem by coming out clearly to issue circulars for its usage by the pupils/students and the workers in government offices. It is hoped that if this approach by the government of Ekiti State is adopted in other parts of the country and the world as a whole, many problems like terrorism, the boko haram problem in Nigeria and a host of other problems will be solved without degenerating into war.

\section{References}

Abduraheem, Nimatallah Modupe. "The Hijāb, Barristers' Dress Code and Religious Freedom in the Legal Profession in Nigeria," 2014. www.unilorin.edu.ng.

Al Bahla, Farihu Ibn Salih. Al-Istihabbu Fi Mã Qila Fi'l Hijäb. Beirut: Dar al Kutub, 1426.

Albani, Muhammad Nasir al-Din. Hijab al-mar'ah al-Muslimah fi al-Kitab wa-alSunnah. Beirut: al-Maktab al-Islami, 1997.

Badawi, Jamal A. Woman under the Shade of Islam. Riyadh: Organization of Islamic Conference, 1998.

Bello, Mufutau Olusola. "Dress Code in Tertiary Institution in Ekiti State: An Islamic Perspective." M.A. Thesis, Department of Religious Studies, Ekiti State University, 2011.

C.L. Adeoye. AsaatiIse Yoruba. London: University Press Limited, 1980.

“Constitution of Nigeria." Accessed January 10, 2021. http://www.concourt.am/armenian/legal_resources/world_constitutio ns/constit/nigeria/nigeri-e.htm.

Ekiti State Government. Ekiti State Annual and Who's Who. Lagos: Medujet Publications, 1999.

———. Ekiti State City Guide. Ado-Ekiti: Kunbi Publishers, 2004.

-__. Ekiti Yellow Pages. Ado-Ekiti: Kalda Investment Ltd., 2005.

Encyclopedia Britannica, Inc. "The New Encyclopedia Britannica." Encyclopedia Britannica, Inc, 2007.

"Fashion in Nigeria." Wikipedia, n.d. https://en.wikipedia.org/wiki/Fashion_in_Nigeria. 
Islam By Country. "World Muslim Population By Percentage 2014 Estimate." Wikipedia, n.d. https://en.m.wikipedia.org/wiki/Islam_by_country.

Khan, Muhammad Muhsin. Sahih Al-Bukhāri Arabic-English. Riyadh: Darussalam, 1994.

Nasidi, Igoli. Culture and Democracy. Zaria: Ahmadu Bello University Press Limited, 2002.

“Religion in Nigeria." Wikipedia, n.d. https://en.m.wikipedia.org/wiki/Religion_in_Nigeria.

Sabiq, As-Sayyid. Fiqh Us-Sunnah. USA: American Trust Publications, 1991.

"Universal Declaration of Human Rights," October 6, 2015. https://www.un.org/en/universal-declaration-human-rights/. 